\title{
Impact of Family Background, Perceived Organizational Support, and Organizational Culture on Entrepreneurial Intention in University Students
}

\author{
Harif Amali Rivai ${ }^{1}$, Syukri Lukman ${ }^{2}$, Hayatul Rahmi ${ }^{3}$ \\ \{harifamali@gmail.com¹, rahmihayatul.hr@gmail.com², cuwy52@gmail.com ${ }^{3}$ \} \\ Management Department, Universitas Andalas, Padang, Indonesia ${ }^{1,2,3}$
}

\begin{abstract}
This study aimed to investigate antecedents of students entrepreneurial intention in higher education context. The antecedents of entrepreneurial intention were predicted from family background, perceived organizational support, and organizational culture. The data were drawn from 148 university students in West Sumatera Province, Indonesia. The model was predicted by multiple regression analysis. The findings concluded that there is significant effect of family background, organizational culture and entrepreneurial significantly influenced students' entrepreneurial intention in the universities. Implication, limitation and suggestion for future research are discussed in the paper.
\end{abstract}

Keywords: Family Background, Perceived Organizational Support, and Organizational Culture Entrepreneurial Intention.

\section{Introduction}

Developing entrepreneurship in higher education has been attention for scholars and practitioners, mainly for developing countries. It is due to the growing numbers of entrepreneurs in a country can accelerate economic development through generating new ideas and utilize them in business activities. Given this prioritization, higher education institutions (i.e. universities) are encouraged to play a more active role by giving support and developing entrepreneurial culture. The universities might respond to this challenge by nurturing programs and activities to stimulate entrepreneurial mind-set among the students. This idea relies on assumption that entrepreneurial skills will prepare students better for their careers in small and large organizations alike. Nevertheless, determinant of entrepreneurial intention might be influence of the strength of family orientation (i.e. family background). The group, organization, or community possesses some potential for entrepreneurial activity. The environment has the potential for increasing entrepreneurial activity. Family background deals with issues relating to an individual's personal and family life. A person with entrepreneurial family background implies that parent possess a high expectation for family members to nurturing their business. It can be argued that family member has moral obligation to maintain sustainability of the business. Entrepreneurial family background refers to those people whose parents or family members are involved in self-employment [1]. As noted by Kolvereid [2], entrepreneurial family background may impact vocational choice to pursue an entrepreneurial career through formation of attitudes, subjective norms, and perceived behavioral control. Impact of family background on developing entrepreneurship has been explored in prior studies. Laspita, Breugst, Heblich, \& Patzelt [3] and Zellweger, Sieger, \& Halter [4] suggested 
that students with family business background which stems from a particular familial context that may influence their future career intentions. The family influence might strengthen their willing to transform these intentions into actual behaviors.

Developing entrepreneurship in higher education context is inevitable from the role of university to encourage students in entrepreneurship activities. Others studies have found that perceived organizational support and organizational culture associated positively with entrepreneurial intention (e.g. Rutherford and Holt [5]; Antoncic and Hisrich [6]; Whiting [7]). Perceived organizational support (POS) is defined as a general belief in which employees feel that their organization values their contributions and cares about their well-being ([8]-[10]). Construct of POS was developed on the basis of Organizational Support Theory [11]. The theory supported that relationships between employers and employees based on social exchange. Employees view the organization as having human like characteristics and take its favorable treatment or unfavorable treatment as an indication that the organization favors or disfavors them as an individual. In the context of the higher education, students who feel sense of POS in the circumstance where they need university support during the students explore entrepreneur knowledge and skill. The students who feel university is willing to lend a helping hand, caring and personally fee respected to develop entrepreneurial activities might be encouraged to be self-directed, self-managing, and proactive [12]. Therefore, it can be argued that POS has impact on encouraging student entrepreneurial intention in higher education context.

The involvement of the higher education institution is all the more important given that this career avenue is becoming more common and necessary choice for students [13]. Given this important, to foster the entrepreneurs, the scholars to understand factors influencing of the student intention from institutional institutional perspective (i.e. organizational culture). Organizational culture defined as shared mental assumptions that guide interpretation and action in organizations by defining appropriate behavior for various situations [14]. Encouragement from university environment is likely to affect the entrepreneurial intention of university students [15]. Therefore, cultural values are also likely to determine "the degree to which a society considers entrepreneurial behaviors, such as risk taking and independent thinking, to be desirable" [16]. The currrent study is intended to examine the factors antecedents of enterprenuerial intention of universities students. Developing body of the literature supported that family background, perceived organizational support, and organizational culture might affect entrepreneurial intention in higher education context.

Entrepreneurship has been an interested topic discussed in these past years. Many studies found that entrepreneurship is one of the most important mechanisms to promote economic growth of a country through innovation, employment, and welfare [17]-[20]. Based on the research conducted by The Global Entrepreneurship and Development Institute to measure the entrepreneurial ecosystem health, Indonesia was ranked $103^{\text {th }}$ out of 132 countries in the world [21].

This is a positive sign since in the previous year Indonesia was only ranked 120th out of 130 countries [22]. Although there was a big gain in ranks for Indonesia, the global entrepreneurship index's score was only increase by 1.72 . This means that the development of entrepreneurship in Indonesia is still limited. Therefore, the promotion of entrepreneurship is important and it has been the main attention of governments. Some studies show that family background is one of the factors that affect entrepreneurial intention

Besides family background, other studies also found that perceived organizational support and organizational culture are positively related to entrepreneurial intention. This research is going to test all the variables mentioned above and see their impacts towards the 
entrepreneurial intention of university students in line with government programs the university graduated is expected to create labor market.

This research is intended to identify the factors influencing entrepreneurial intention that will contribute to the formation of entrepreneurs so that the best strategy can be implemented to increase the numbers of entrepreneurs in Indonesia.

\section{Review of Literature}

\subsection{Entrepreneurial Intention}

Entrepreneurship is "the process of creating something different with value by devoting the necessary time and effort, assuming the accompanying financial, psychological, and social risks, and receiving the resulting reward of monetary and personal satisfaction" [23][24]. According to Academy of Management entrepreneurship is "the creation and management of new businesses, small businesses, and family businesses" [25]. Entrepreneurial intention is a tendency of individual desire to do entrepreneurship activity by creating new products through business opportunity and propensity taking [26]-[28]. The notion of prediction behavior through intention adpoted from work of Fishbein and Ajzen [29]. It plays an essential role which reflects an evolutionary transition from beliefs to attitudes, from attention to intention and finally from intention to behavior. It can be argued that the development of behavior can be understood as somehow determined or planned. Entrepreneurial intention indicates the effort that the person will make to carry out entrepreneurial behavior. For this reason, it consists of three motivational factors influencing behavior; personal attitude toward start-up, subjective norm, and perceived behavioral control [30][31]. The entrepreneurial intention is the motivational factor that encourages individuals to pursue entrepreneurial activities. Entrepreneur action is driven by intentional. Entrepreneurs intend to pursue certain opportunities, enter new market, and offer new product and this is rarely the process of unintentional behavior. Developing a model entrepreneurial intention will be rigor by considering beyond the personality attributes (e.g. family background, organizational support, and organizational culture).

\subsection{Family Background and Entrepreneurial Intention}

Personal/Family variable associated with issues relating to an individual's personal and family life. Paramount to success is finding support from family and friends during the developmental phase of a business start-up [32]. Family support and life balance are equally critical in order to succeed in starting a business start-up [33]. Issues regarding the personal life of an entrepreneur may interfere with the operation of the business, which may ultimately cause the business to grow or fail. Entrepreneurial family background may impact vocational choice to pursue an entrepreneurial career through formation of attitudes, subjective norms, and perceived behavioral control. There are several pieces of evidence in student entrepreneurship literature suggesting that students with family business background stem from a particular familial context that may influence their future career intentions [3][4] and strengthen their proclivity to transform these intentions into actual behaviors. A number of empirical studies have suggested the importance of parental experience, revealing its significant impact on children's entrepreneurial intentions and behavior [34]-[38].

In scientific research, the influence of family background, especially the influence of the father or mother, on the entrepreneurial career choice has been empirically supported. Several 
studies support that family background is related to the propensity to choose self-employment as a career [37][39]. For example, Singh and DeNoble [40] argued that a close, self-employed relative has a strong positive impact on the attitude on self-employment. The influence of parents as model is assumed to be a powerful determinant [41]. Moreover, Klandt [42] found that the father's profession has an effect on the occupational decision of the son and the daughter, while the mother's influence is mostly limited to the daughter. Therefore the hypothesis can be proposed: H1: Family background significantly effects on student's entrepreneurial intention.

\subsection{Perceived Organizational Support and Entrepreneurial Intention}

Perceived Organizational Support (POS) is the beliefs of employees in regards to the extent to which the organization meets their socio-emotional needs, and how the organization responds to increased efforts at work [8], [10], [11]. A few factors are believed to influence whether employees perceive organizational support, such as organizational rewards and job conditions, and perceived fairness [43]. Organizational rewards and job conditions incorporate methods in which employees are recognized for their contributions as well as the working environment itself [9].

Perceived Organizational Support is important as it guarantees assistance provided by the organization to deal with the demanding conditions, and to carry out ones job efficiently and effectively [44]. People need to be valued and they are more concerned with the commitment of the organization to them, and being valued by the organization yield such benefits like pay, promotion, admiration, other forms of aids, and access to information by which they can carry their jobs better.

According to social exchange theory employees who perceive their organizational environment as supportive will feel obligated to reciprocate with behaviors that are beneficial to the organization. From this view point, it could be expected that perceived organizational support mediates the effects of human resources practices on entrepreneurship, because positive feelings about the organization and its supportive nature could positively influence employees' receptivity towards the organization's efforts to introduce and implement entrepreneurship [5]. Antoncic and Hisrich [6] also suggest that organizational support characteristics such as management support, work discretion, rewards, time availability, and loose intra-organizational boundaries have been seen to be crucial organizational elements impacting entrepreneurship. Therefore the hypothesis can be proposed:

H2: Perceived organizational support (POS) significantly effect on the student's entrepreneurial intention.

\subsection{Organizational Culture and Entrepreneurial Intention}

Understanding the culture of an organization is important in order to remove the challenges faced by the organization in the process of making organizational changes. Organizational culture is generally seen as a set of key values, assumptions, understandings, and norms that is shared by members of an organization and taught to new members as correct [45].Organizational culture creates the value of an institution not only by the manners and behaviors of every individual in the organization but also by the collective attitudes and behavior of the organization in general [46]. It is the pattern of values, norms, beliefs, attitudes as well as assumptions that may not be expressed but shapes the ways in which people in an 
organization conduct themselves and get things done [47]. A model of norms, values, beliefs, and attitudes has a significant effect on organizational behavior [48].

A culture creates distinctions between one organization and others, conveys a sense of identity for its members, facilitates commitment towards the organization's goals, enhances the stability of the social system, reduces ambiguity, and serves as a control mechanism that guides and shapes the attitudes and behavior of employees. Nevertheless, a culture can also become a liability when it becomes too strongly entrenched within the norms, values and mindsets of the employees and resist changes, a culture can become a barrier to change, diversity and other transformations required for the organization to adapt in today's dynamic, globalized business environment.Organizational culture can reinforce or weaken the effects of national culture on an organization's entrepreneurial orientation [49]. Hofstede [50] has demonstrated the role of firm founder's values on organizational culture and the interaction between national and corporate value systems. Organizational culture, in addition to the capability to integrate daily activities of employees to reach the planned goals, can also help organizations adapt well to the external environment for rapid and appropriate responses. Understanding culture means understanding the difference between the formal and informal rules, the espoused way of doing things and the real way. The organizational culture profile can be viewed from three stereotypical dimensions: bureaucratic, innovative, and supportive [51]. Bureaucratic cultures attributed by hierarchical and compartmentalized, clear line of responsibility and authority, based on control and power. This kind of culture is appropriate for company or organization operates in a large and stable market. Innovative culture refers to entrepreneurial and ambitious characters of organizational members in which the organization operates in dynamic environment. Innovative environment is appropriate for individuals who possess attributes of entrepreneur, such as challenging, stimulating, creative, results-oriented and risk-taking. Meanwhile, supportive culture reflects organizational members act friendly, fair, and helpful each other. This type of culture also attributes people with open minded and harmonious environment. An organization has highly supportive environment if it is trusting, safe, equitable, sociable, encouraging, open, relationship oriented, and collaborative [51]. Veciana et al., [52] suggest that entrepreneurship might be developed in the higher education context through a process-based approach. Nevertheless, the robustness of entrepreneurial intention will be affected by cultural contexts. Hayton et al [16] noted that cultural values are also likely to determine "the degree to which a society considers entrepreneurial behaviors, such as risk taking and independent thinking, to be desirable" (p. 33). Therefore the hypothesis can be proposed: H3: Organizational culture significantly effect on student's entrepreneurial intention

\section{Methodology}

Self-report questionnaires were distributed directly to Andalas university students in West Sumatera Province. A total 150 questionnaires were distributed, 148 were returned. Measurement variable of family background, perceived organizational support, organizational culture, entrepreneurial intention and start-up were adopted and developed on the basis of established existing variables from previous studies. All variables were measured with 5-point Likert type scaling from 1 (strongly disagree) to 5 (strongly agree). Family background was measured by ten items which were adapted from Dombrovsky and Welter [53]. Perceived organizational support was measured by sixteen items which were adapted from Eisenberger et. al [11]. Organizational culture was measured by twenty four item with three dimension. The measurement were adapted from Roper [54]. Entrepreneurial intention was measured by 
five items which were adapted from Linan and Chen [55]. Data analysis was conducted by using SPSS for Windows. Reliability check of the variables was computed using cronbach alpha. Usual lower limit of cronbach alpha range between 0.6 and 0.7 [56]. Testing of hypotheses was conducted by multiple regression analysis. The analysis is purported to explain the effect of family background, perceived organizational support, and organizational culture on entrepreneurial intention.

\section{Results}

The mean, standard deviation and correlation matrix for the study this variables are shown in table 1. Estimated correlation among the construct shown that all correlations did not greater than 0.7 . They did not indicate the multicollinearity of the problems of lack of discriminant validity. Test of reliability or reliability test is a test to examine the accuracy and measurement precision of measurement tool which is consistent over time. In this research, the reliability is determined by the value of Cronbach alpha. Cronbach alpha of family background, perceived organizational support, organizational culture, and entrepreneurial intention is $0.73,0.85,0.89$. and 0.79 respectively. It can be concluded that all four variables demonstrated a good reliability.

Table 1. Cronbach alpha, Means, Standard Deviation, and Correlation

\begin{tabular}{|c|l|l|l|l|l|l|l|}
\hline & \multicolumn{1}{|c|}{ CA } & \multicolumn{1}{|c|}{ Mean } & \multicolumn{1}{|c|}{ SD } & $\mathbf{1}$ & $\mathbf{2}$ & $\mathbf{3}$ & $\mathbf{4}$ \\
\hline FB & 0.73 & 4.38 & 0.71 & & & & \\
\hline POS & 0.85 & 3.72 & 0.69 & $0.63^{*}$ & & & \\
\hline OC & 0.89 & 3.92 & 0.81 & $0.40^{*}$ & $0.36^{*}$ & & \\
\hline EI & 0.79 & 4.12 & 0.95 & $0.56^{*}$ & $0.43^{*}$ & $0.46^{*}$ & \\
\hline
\end{tabular}

Note: $* p \leq 0.05$. FB: family background, POS: perceived organizational support, OC:

Organizational Support, EI: entrepreneurial intention

Table 2. Regression Analysis

\begin{tabular}{|l|l|l|l|l|}
\hline \multicolumn{1}{|c|}{ Variable } & $\boldsymbol{\beta}$ & P value & F & $\mathbf{R}^{\mathbf{2}}$ \\
\hline Family background & 0.44 & 0.042 & 0.032 & 0.39 \\
\hline POS & 0.52 & 0.039 & & \\
\hline Organizational Cuture & 0.39 & 0.022 & & \\
\hline
\end{tabular}

The survey results noted that out of the total respondents $(\mathrm{N}=148)$. They consists of 43.9 percent man and 56.1 percent woman. The student's age average is 20.5 years old with range between 16 to 24 years old. The descriptive of the survey found that 83.8percent plan to start a business and the rest continues study to higher degree.

The results of regression analysis (Table 2) found that family background, perceived organizational support, and organizational culture as significant determinant of entrepreneurial intention in higher education context. It can be concluded that family background, perceived organizational support significantly influence intention of the students to be entrepreneur. Therefore, the proposed hypothesis 1, 2, and 3 are supported. 


\section{Discussion}

The results of testing hypotheses supported that family background, perceived organizational support, and organizational culture significantly effects intention of the students to be entrepreneur. It indicates that those with family background tends to have motivation to be entrepreneur. Supporting from family and friends can bring success of the student to start a business [32]. Knight [33] argued family support and life balance are equally critical in order to succeed in starting a business start-up. Developing body of literature in student entrepreneurship suggests that students with family business background stem from a particular familial context that may influence their future career intentions [3][4]. This situation strengthen their proclivity to transform these intentions into actual behaviors. The current research findings consistent with findings from prior studies which suggested the importance of parental experience, revealing its significant impact on children's entrepreneurial intentions and behavior [34]-[38]. In line with findings from Scherer, Brodzinski, \& Wiebe [41], those noted the influence of parents as a model is regarded as crucial determinant of entrepreneurial intention. Klandt [42] argued that family backround effect on the occupational decision of the son and the daughter, while the mother's influence is mostly limited to the daughter. Therefore, students with a strong family business background tends to have higher intention rather than their non-business family background.

The result of testing hypotheses 2 showed that effect of perceived organizational support on entrepreneurial intention significantly influenced entrepreneurial intention on the students. This findings is supported by previous study conducted by Rutherford and Holt [5]. Their study noted that positive feelings about the organization and its supportive nature could positively influence employees' receptivity towards the organization's efforts to introduce and implement entrepreneurship. Antoncic and Hisrich [6] also stated that organizational support characteristics such as management support, work discretion, rewards, time availability, and loose intra-organizational boundaries have been seen to be crucial organizational elements impacting entrepreneurship. It practically happens because of differential of respondent's characteristic, differential of research object, and differential of time research observation. Bertolino et al [57] noted that individuals with prototypical proactive personality take action to influence their environment or "identify opportunity or act on them shows initiative, take action, and persevere until meaningful change occurs" (p.249).

Rhoades \& Eisenberger [9] noted that there are three important points of perceived organizational support. Perceived organizational support should produce a felt obligation to care about the organization's welfare and to help the organization reach its objectives, POS should fulfill socio-emotional needs, leading workers to incorporate organizational membership and role status into their social identity. In the context of higher education, perceived organizational behavior can be felt as university giving support to the students to toward various activities both academics and no-academics activities. It is includes activities to nurturing entrepreneurship. Feeling support may increase students' proactivity which characterized by initiatives and assertiveness. This characteristics can encourage students to be self-managed and self-directed [12] which in turn increasing entrepreneurial intention. Therefore, perceived organizational support felt by students will increase students' entrepreneurial intention. The higher feeling support from the university, the higher intention of the students to conduct entrepreneurial activities.

The recent study supported organizational culture significantly affect entrepreneurial intention of students to be entrepreneur. According to Wallach [51] organizational culture can be view from three dimension: innovative, supportive, and bureaucratic. A testing of 
composite dimensions found that organizational culture as significant predictor of entrepreneurial intention. Others studies conducted by Schere [58], Begley [59], and Whiting [7] argues that cultures with higher uncertainties will affect on entrepreneurial intentions.

\section{Conclusion}

The results of regression demonstrated that family background has significant influences toward student's entrepreneurial intention This result explains positive value that indicates the influence brings positive impact which means increase of family background of students. It will impact and attract more entrepreneurial intention to them. The student's perceived organizational support has significant influence towards student's entrepreneurial intention. Developing organizational culture, mainly entrepreneurial culture can accelerate student's entrepreneurial intention. Entrepreneurial intention is necessary to be developed for university graduated career. This result explains positive value and indicates the influences will impact and attract more start-up.

The current research has several limitation and suggestion for future research. This research is limited on sampling location of universities and number of sample size. Future researchers are suggested to enlarge the sample size of respondents to better represent the opinion of whole undergraduates' population, from private and public institutions. Future studies suggest to conduct the research in higher learning institutions in a broader context order to get higher accuracy of the university student's feedback to avoid the bias. The limitation of the research also includes methodology to collect the data The current study relied quantitative approach, future researchers suggest to use other combination of data collection methods like interviews. This can increase the participation of respondents and interviewers can get more opinions from multiple perspectives. Undergraduates from all faculties should be taken into consideration to get better insight into entrepreneurial intention and continue to start-up activity. Besides, this study only highlights the university students, different perspective and group's skill tendency of individual might have different thinking towards entrepreneurship. Thus, opinions from individual of different faculty should be considered. Entrepreneurial intention is regarded as strong predictor of entrepreneurial action. This research study only examines the entrepreneurial intention rather than actual business start-up activities. It appears to be impracticable in the real life and it requires a longer duration to monitor the actual action. Researchers also did not take into consideration about the opinions from different ethnic groups. It is one of the aspects that required attention as individuals from different ethnic group might have different perception toward entrepreneurship, and their entrepreneurial intention might vary. In order to obtain a more accurate result, all the respondents should be randomly chosen from different ethnic groups.

Implications of the study can explained from higher educational strategy toward developing entrepreneurial intention through supporting students with entrepreneur family background to create entrepreneurial programs in the university. The universities might develop circumstance that encourages the students to motivate for entrepreneurship programs. It is inline with nurturing organizational culture (i.e. entrepreneurial culture) in the universities. Therefore, the universities can take into account to support activities which can facilitate students to creative.

\section{References}

[1] T. J. Bae, S. Qian, C. Miao, and J. O. Fiet, "The relationship between entrepreneurship education and entrepreneurial intentions: A meta-analytic review," Entrep. theory 
Pract., vol. 38, no. 2, pp. 217-254, 2014.

[2] L. Kolvereid, "Prediction of employment status choice intentions," Entrep. Theory Pract., vol. 21, no. 1, pp. 47-58, 1996.

[3] S. Laspita, N. Breugst, S. Heblich, and H. Patzelt, "Intergenerational transmission of entrepreneurial intentions," J. Bus. Ventur., vol. 27, no. 4, pp. 414-435, 2012.

[4] T. Zellweger, P. Sieger, and F. Halter, "Should I stay or should I go? Career choice intentions of students with family business background," J. Bus. Ventur., vol. 26, no. 5, pp. 521-536, 2011.

[5] M. W. Rutherford and D. T. Holt, "Corporate entrepreneurship: An empirical look at the innovativeness dimension and its antecedents," J. Organ. Chang. Manag., vol. 20, no. 3, pp. 429-446, 2007.

[6] B. Antoncic and R. D. Hisrich, "Corporate entrepreneurship contingencies and organizational wealth creation," J. Manag. Dev., vol. 23, no. 6, pp. 518-550, 2004.

[7] B. G. Whiting, "Creativity and entrepreneurship: how do they relate?," J. Creat. Behav., 1988.

[8] J. Krishnan and V. S. Mary, "Perceived organisational support-an overview on its antecedents and consequences," Int. J. Multidiscip. Res., vol. 2, no. 4, pp. 2-3, 2012.

[9] L. Rhoades and R. Eisenberger, "Perceived organizational support: a review of the literature.," J. Appl. Psychol., vol. 87, no. 4, p. 698, 2002.

[10] R. P. Settoon, N. Bennett, and R. C. Liden, "Social exchange in organizations: Perceived organizational support, leader-member exchange, and employee reciprocity.," J. Appl. Psychol., vol. 81, no. 3, p. 219, 1996.

[11] R. Eisenberger, R. Huntington, S. Hutchison, and D. Sowa, "Perceived organizational support.," J. Appl. Psychol., vol. 71, no. 3, p. 500, 1986.

[12] S. M. K. Hashemi, H. K. Nadi, S. M. Hosseini, and A. Rezvanfar, "Agricultural Personnel's Proactive Behavior: Effects of Self Efficacy Perceptions and Perceived Organizational Support," Int. Bus. Manag., vol. 4, no. 1, pp. 83-91, 2012.

[13] Y. Gasse and M. Tremblay, "Entrepreneurial beliefs and intentions: a cross-cultural study of university students in seven countries," Int. J. Bus., vol. 16, no. 4, p. 303, 2011.

[14] D. Ravasi and M. Schultz, "Responding to organizational identity threats: Exploring the role of organizational culture," Acad. Manag. J., vol. 49, no. 3, pp. 433-458, 2006.

[15] D. Turker and S. Sonmez Selçuk, "Which factors affect entrepreneurial intention of university students?," J. Eur. Ind. Train., vol. 33, no. 2, pp. 142-159, 2009.

[16] J. C. Hayton, G. George., and S. A. Zahara, "Cultural cluster: Methodology and findings," J. World Bus., vol. 26, no. 4, pp. 33-53, 2002.

[17] D. W. Elfenbein, B. H. Hamilton, and T. R. Zenger, "The small firm effect and the entrepreneurial spawning of scientists and engineers," Manage. Sci., vol. 56, no. 4, pp. 659-681, 2010.

[18] M. Guerrero, J. Rialp, and D. Urbano, "The impact of desirability and feasibility on entrepreneurial intentions: A structural equation model," Int. Entrep. Manag. J., vol. 4, no. 1, pp. 35-50, 2008.

[19] I. Verheul, R. Thurik, I. Grilo, and P. Van der Zwan, "Explaining preferences and actual involvement in self-employment: Gender and the entrepreneurial personality," J. Econ. Psychol., vol. 33, no. 2, pp. 325-341, 2012.

[20] Y. Zhang, G. Duysters, and M. Cloodt, "The role of entrepreneurship education as a predictor of university students' entrepreneurial intention," Int. Entrep. Manag. J., vol. 10, no. 3, pp. 623-641, 2014. 
[21] Z. J. Ács, L. Szerb, and E. Autio, Global entrepreneurship and development index 2016. Springer, 2016.

[22] Z. J. Ács, L. Szerb, and E. Autio, Global entrepreneurship and development index 2015. Springer, 2015.

[23] R. D. Hisrich, "The woman entrepreneur: characteristics, skills, problems and prescriptions for success," art Sci. Entrep., pp. 61-81, 1986.

[24] S. Shane and S. Venkataraman, "The promise of entrepreneurship as a field of research," Acad. Manag. Rev., vol. 25, no. 1, pp. 217-226, 2000.

[25] M. Coulter, Entrepreneurship in Action, 2nd ed. Prentice Hall, 2003.

[26] T. Ramayah and Z. Harun, "Entrepreneurial intention among the student of Universiti Sains Malaysia (USM)," Int. J. Manag. Entrep., vol. 1, no. 1, pp. 8-20, 2005.

[27] S. Kristiansen and N. Indarti, "Entrepreneurial intention among Indonesian and Norwegian students," J. Enterprising Cult., vol. 12, no. 1, pp. 55-78, 2004.

[28] R. J. Taormina and S. Kin-Mei Lao, "Measuring Chinese entrepreneurial motivation: Personality and environmental influences," Int. J. Entrep. Behav. Res., vol. 13, no. 4, pp. 200-221, 2007.

[29] M. Fishbein and I. Ajzen, Belief, attitude, intention, and behavior: An introduction to theory and research. Addison-Wesley, 1975.

[30] I. Ajzen, "The theory of planned behavior," Organ. Behav. Hum. Decis. Process., vol. 50, no. 2, pp. 179-211, 1991.

[31] F. Liñán, "Intention-based models of entrepreneurship education," Piccolla Impresa/Small Bus., vol. 3, no. 1, pp. 11-35, 2004.

[32] J. Hatala, "Identifying barriers to self-employment: the development and validation of the barriers to entrepreneurship success tool," Perform. Improv. Q., vol. 18, no. 4, pp. 50-70, 2005.

[33] R. M. Knight, “The process of entrepreneurship,” J. Small Bus. Entrep., vol. 13, no. 2, pp. 3-13, 1996.

[34] D. D. Bowen and R. D. Hisrich, "The female entrepreneur: A career development perspective," Acad. Manag. Rev., vol. 11, no. 2, pp. 393-407, 1986.

[35] J. C. Carr and J. M. Sequeira, "Prior family business exposure as intergenerational influence and entrepreneurial intent: A theory of planned behavior approach," J. Bus. Res., vol. 60, no. 10, pp. 1090-1098, 2007.

[36] P. Dubini, "The influence of motivations and environment on business start-ups: Some hints for public policies," J. Bus. Ventur., vol. 4, no. 1, pp. 11-26, 1989.

[37] M. G. Scott and D. F. Twomey, "The long-term supply of entrepreneurs: students' career aspirations in relation to entrepreneurship," J. small Bus. Manag., vol. 26, no. 4, p. $5,1988$.

[38] H. Van Auken, F. L. Fry, and P. Stephens, "The influence of role models on entrepreneurial intentions," J. Dev. Entrep., vol. 11, no. 2, pp. 157-167, 2006.

[39] R. Bennett and S. Dann, "The changing experience of Australian female entrepreneurs," Gender, Work Organ., vol. 7, no. 2, pp. 75-83, 2000.

[40] G. Singh and A. DeNoble, "Views on self-employment and personality: An exploratory study," J. Dev. Entrep., vol. 8, no. 3, p. 265, 2003.

[41] R. F. Scherer, J. D. Brodzinski, and F. A. Wiebe, "Entrepreneur career selection and gender: A socialization approach," J. small Bus. Manag., vol. 28, no. 2, p. 37, 1990.

[42] H. Klandt, Aktivität und Erfolg des Unternehmungsgründers: eine empirische Analyse unter Einbeziehung des mikrosozialen Umfeldes. Eul, 1984.

[43] B. E. Baran, L. R. Shanock, and L. R. Miller, "Advancing organizational support 
theory into the twenty-first century world of work," J. Bus. Psychol., vol. 27, no. 2, pp. 123-147, 2012.

[44] J. M. George, T. F. Reed, K. A. Ballard, J. Colin, and J. Fielding, "Contact with AIDS patients as a source of work-related distress: Effects of organizational and social support," Acad. Manag. J., vol. 36, no. 1, pp. 157-171, 1993.

[45] R. L. Daft and P. G. Lane, "The leadership experience (3rd)," Mason, Ohio Thomson South-Western, 2005.

[46] M. Aksoy, S. Apak, E. Eren, and M. Korkmaz, "Analysis of the effect of organizational learning-based organizational culture on performance, job satisfaction and efficiency: a field study in banking sector," Int. J. Acad. Res., vol. 6, no. 1, 2014.

[47] M. Armstrong, A handbook of human resource management practice. Kogan Page Publishers, 2006.

[48] E. Aktaş, I. Çiçek, and M. Kıyak, "The effect of organizational culture on organizational efficiency: The moderating role of organizational environment and CEO values," Procedia-Social Behav. Sci., vol. 24, pp. 1560-1573, 2011.

[49] A. Fayolle, O. Basso, and V. Bouchard, "Three levels of culture and firms' entrepreneurial orientation: A research agenda," Entrep. Reg. Dev., vol. 22, no. 7-8, pp. 707-730, 2010.

[50] G. Hofstede and G. J. Hofstede, Culture and Organizations (Software of the Mind) McGraw-Hill. McGraw-Hill, 2005.

[51] E. J. Wallach, "Individuals and organizations: The cultural match.," Train. Dev. J., 1983.

[52] J. M. Veciana, M. Aponte, and D. Urbano, "University students' attitudes towards entrepreneurship: A two countries comparison," Int. Entrep. Manag. J., vol. 1, no. 2, pp. 165-182, 2005.

[53] V. Dombrovsky and F. Welter, "The role of personal and family background in making entrepreneurs in a post-socialist environment," Available SSRN 1697581, 2006.

[54] E. Roper, "Moving toward improved acquisition outcomes: The interrelationships between culture, commitment, and leadership," DEFENSE ACQUISITION UNIV FT BELVOIR VA, 2011.

[55] F. Liñán and Y. Chen, "Development and cross-cultural application of a specific instrument to measure entrepreneurial intentions," Entrep. theory Pract., vol. 33, no. 3, pp. 593-617, 2009.

[56] J. F. Hair, W. C. Black, B. J. Babin, and R. E. Anderson, "Multivariate Data Analysis," Vectors. p. 816, 2010.

[57] M. Bertolino, D. M. Truxillo, and F. Fraccaroli, "Age as moderator of the relationship of proactive personality with training motivation, perceived career development from training, and training behavioral intentions," J. Organ. Behav., vol. 32, no. 2, pp. 248 263, 2011.

[58] J. L. Schere, "Tolerance of Ambiguity as a Discriminating Variable Between Entrepreneurs and Managers.," in Academy of management proceedings, 1982, vol. 1982, no. 1, pp. 404-408.

[59] T. M. Begley and D. P. Boyd, "A comparison of entrepreneurs and managers of small business firms," J. Manage., vol. 13, no. 1, pp. 99-108, 1987. 